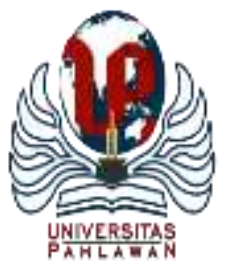

Edukatif : Jurnal Ilmu Pendidikan Volume 3 Nomor 6 Tahun 2021 Halm 4160 - 4171

EDUKATIF: JURNAL ILMU PENDIDIKAN

Research \& Learning in Education

https://edukatif.org/index.php/edukatif/index

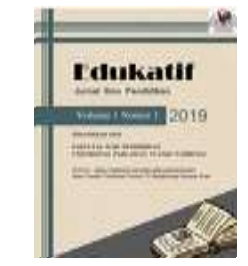

\title{
Pengembangan Modul Kimia Pendekatan Saintifik pada Materi Laju Reaksi di Madrasah Aliyah (MA)
}

\author{
Isniatun Hasanah ${ }^{1}$, Husna Amalya Melati ${ }^{2 凶}$, Rahmat Rasmawan $^{3}$ \\ Universitas Tanjungpura, Indonesia ${ }^{1,2,3}$ \\ E-mail : $\underline{\text { isni@ } \text { student.untan.ac.id }}{ }^{1}, \underline{\text { h.a.melati@ chem.edu.untan.ac.id }}{ }^{2}, \underline{\text { rahmat.rasmawan@ } @ \text { fkip.untan.ac.id }}^{3}$
}

\begin{abstract}
Abstrak
Penelitian ini bertujuan untuk menentukan tingkat kelayakan dan respon siswa pada modul kimia pendekatan saintifik pada materi laju reaksi. Metode yang digunakan dalam penelitian ini ialah penelitian pengembangan menggunakan model ADDIE. Subjek pada penelitian ini adalah modul kimia pendekatan saintifik dan subjek uji cobanya yaitu peserta didik yang terdapat di MA Darul Ulum Kubu Raya. Uji kelayakan diuji berdasarkan aspek isi, penyajian, bahasa, dan kegrafikan. Presentase rata-rata pada aspek validasi kelayakan berturut-turut mendapatkan skor 93,33\% (sangat layak), 86,66\% (sangat layak), 94,66\% (sangat layak), dan 83,99\% (sangat layak). Berdasarkan hasil dari perhitungan angket respon peserta didik terhadap modul kimia pendekatan saintifik menunjukkan bahwa hasil dari uji coba kelompok kecil mendapatkan presentase sebesar 87,71\% memiliki kategori kriteria penilaian yaitu sangat tinggi sedangkan pada uji lapangan mendapatkan presentase sebesar $88,79 \%$ memiliki kategori kriteria penilaian yaitu sangat tinggi. Dengan demikian, modul kimia pendekatan saintifik bisa digunakan sebagai bahan pendukung pembelajaran dalam materi laju reaksi.
\end{abstract}

Kata Kunci: modul, pendekatan saintifik, laju reaksi

\section{Abstract}

This study aims to determine the level of feasibility and student responses to the chemical module of the scientific approach on the reaction rate material. The method used in this research is development research using the ADDIE model. The subject in this study was the chemistry module of the scientific approach and the test subjects are the students in MA Darul Ulum Kubu Raya. The feasibility test was tested based on aspects of content, presentation, language, and graphics. The average percentage of the feasibility validation aspect scored $93.33 \%$ (very feasible), $86.66 \%$ (very feasible), $94.66 \%$ (very feasible), and $83.99 \%$ (very feasible). Based on the results of the calculation of the student responses questionnaire to the scientific approach chemistry module, it shows that the results of the small group trial get a percentage of $87.71 \%$ having the category of assessment criteria which is very high while in the field test getting a percentage of $88.79 \%$ having the category of assessment criteria that is very high. Thus, the chemistry module with a scientific approach can be used as a learning support material in the reaction rate material.

Keywords: module, scientific approach, the reaction rate

Copyright (c) 2021 Isniatun Hasanah, Husna Amalya Melati, Rahmat Rasmawan

$\triangle$ Corresponding author:

Email: : h.a.melati@chem.edu.untan.ac.id

DOI : https://doi.org/10.31004/edukatif.v3i6.746

ISSN 2656-8063 (Media Cetak)

ISSN 2656-8071 (Media Online)

Edukatif : Jurnal Ilmu Pendidikan Vol 3 No 6 Tahun 2021 p-ISSN 2656-8063 e-ISSN 2656-8071 


\section{PENDAHULUAN}

Salah satu langkah perangkat pembelajaran yang digunakan sebagai perantara pada kegiatan belajar kimia yaitu modul. Berbagai buku bisa dipakai sebagai perantara pada proses belajar Kimia, seperti modul. Menurut (Bahtiar, 2015) bahan ajar atau modul yang dikembangkan sebaiknya didalamnya terdapat isi yang bisa sesuai dan bisa diberikan secara urut supaya bisa mencapai tujuan pada materi pembelajaran dan bisa menambah wawasan peserta didik. Menurut (Sawitri \& Ambarwati, 2014) menyatakan bahwa pengembangan modul menggunakan pendekatan saintifik sangat layak digunakan didalam proses pembelajaran keanekaragaman hayati.

Pada proses pembelajaran di sekolah, peserta didik juga memerlukan modul yang mendukung siswa mengerti konsep untuk sampai pada tujuan belajar sesuai kecepatan siswa. Pemilihan bahan ajar berupa modul karena tujuan dari penggunaan modul yaitu supaya siswa bisa mematuhi proses belajar dengan kecepatan serta kemampuannya sendiri (Suryosubroto, 2009). Satu paket desain bahan ajar, mencakup tahapan yaitu tujuan belajar, petunjuk penggunaan, kegiatan belajar, daftar pustaka, serta soal (Daryanto, 2014). Penggunaan bahan ajar di dalam mengajar tidak hanya memandang aktifitas guru saja, selanjutnya bisa menyertakan siswa aktif ketika belajar. Modul yang akan dikembangkan yaitu menggunakan pendekatan saintifik.

Kurangnya sumber belajar yang masih belum ada untuk Pendekatan Ilmiah pada kegiatan belajar serta buku yang sudah ada mengutamakan supaya siswa bisa mengingat konsep yang terdapat dalam bahan ajar dari pada membentuk pengetahuan siswa saat menyusun pengetahuan serta keahlian peserta didik untuk mendapatkan konsep yang wajib dimengerti oleh siswa, dan mendapatkan keterlibatan dalam lingkungan sekitar. Pendekatan Ilmiah umumnya menyertakan tahap mengamati yang perlu untuk merumuskan hipotesis. Modul meggunakan Pendekatan Ilmiah ini yang didalamnya terdapat beberapa tahap yaitu 5M diantaranya tahap melihat, menanyakan, menggabungkan data, menalar, serta mengomunikasikan (Mardiana, 2018). Pada Pendekatan Ilmiah peserta didik bisa bersikap tanggung jawab untuk membentuk sikap memang benar bahwa pada pendekatan saintifik pendekatan yang diharuskan untuk mencapai SKL.

Kimia dikembangkan oleh ilmuan berdasarkan hasil penemuan melalui langkah-langkah pendekatan saintifik. Ilmu kimia ditemukan dari hasil beberapa konsep. Ilmu kimia di temukan dari beberapa percobaan. Hasil penemuan tersebut dinyatakan dengan konsep-konsep yang mendasarinya suatu ilmu kimia yang saling berhungan. Hasil percobaan tersebut dibuat ilmuan berdasarkan konsep. Jadi, konsep ini ditemukan dari hasil penemuan.

Berdasarkan hasil wawancara, pembelajaran kimia terhadap materi laju reaksi ialah memiliki karateristik bersifat hafalan, hitungan, dan siswa masih belum mampu untuk mengkaitkan materi laju reaksi kedalam lingkungan sekitar, dikarenakan pemahaman konsep masih abstrak. Selama ini dalam proses pembelajaran siswa hanya memperoleh aspek pengetahuan dengan melalui tahap-tahap mengingat, memahami, dan menganalisis, sedangkan kegiatan pada aspek pendekatan saintifik (pendekatan ilmiah) dengan melakukan tahap-tahap melihat, menanyakan, menggabungkan data, menalar, serta mengomunikasi masih jarang di terapkan.

Modul ini dikembangan proses pemahaman konsep yang didapatkan setelah peserta didik melakukan proses belajar memakai Pendekatan Ilmiah ialah (1) tahap melihat didalamnya memuat hasil pengamatan peserta didik terhadap gambar yang berkaitan dengan laju reaksi yang terdapat didalam kehidupan sehari-hari, (2) tahap menanya didalamnya terdapat proses menanyakan hasil pengamatan pada saat melakukan tahap mengamati, (3) tahap mengumpulkan informasi pada tahap ini peserta didik bisa menemukan suatu konsep yang ingin dicapai karena didalamnya memuat materi yang sudah dijabarkan yang dapat membuat peserta didik paham akan konsep laju reaksi pada modul yang dikembangkan ini dan setelah mengumpulkan informasi peserta didik memberika jawaban pertanyaan yang sudah ditanyakan pada tahap menanya.(4) tahap 
mengasosiasi/menalar didalamnya memuat soal yang berkaitan dengan laju reaksi dan (5) tahap mengomunikasikan dengan memberikan kesimpulan berdasarkan hasil dari mengasosiasi/menalar.

Selama ini ketika belajar didalam kelas siswa mendapatkan aspek pengetahuannya saja dengan melalui tahap-tahap mengingat, memahami, dan menganalisis sedangkan proses kegiatan terhadap aspek pendekatan saintifik ini dengan penerapan tahap-tahap melihat, menanyakan, menggabungkan data, menalar, serta mengomunikasikan masih jarang diterapkan didalam proses pembelajaran yang berlangsung. Selain itu, peserta didik mengatakan bahwa bahan ajar yang digunakan masih terdapat kelemahannya, separti tampilan pada modul pengayaan yang digunakan sangatlah sederhana masih menggunakan warna hitam dan putih serta modul pengayaan yang ada juga masih belum mengajak peserta didik untuk menganalisis atau mengamati gambar yang terdapat pada modul tersebut. Pada saat guru menjelaskan dengan menggunakan modul, guru hanya menjelaskan definisi dan menunjukkan gambar yang ada akan tetapi masih belum meminta siswa melaksakan tahap-tahap pendekatan saintifik. Sehingga siswa hanya menerima serta mendengarkan penjelasan dari guru.

Siswa mengutarakan modul pengayaan yang dipakai masih belum ada kaitannya dalam kehidupan sehari-hari serta masih belum menarik minat siswa untuk belajar modul pengayaan. Maka dari itu perlu modul yang bisa mendukung guru menggunakan Pendekatan Ilmiah. Supaya siswa bisa bersungguh-sungguh pada materi pembelajaran yaitu dengan adanya modul kimia Pendekatan Ilmiah ini bermaksud untuk salah satu solusi yang bisa mendukung siswa untuk bersungguh-sungguh dalam belajar. (Mustika \& Sophia, 2019) menerangkan pemakain modul saat proses belajar maksimal dan praktis serta modul mewajibkan supaya para peserta didik bisa melakukan proses pembelajaran secara mandiri.

Hasil dari pemaparan yang sudah dijelaskan diatas bahwa masih belum tersedianya modul yang dapat menarik peserta didik untuk mempelajarinya serta modul tersebut masih belum ada tahapan pendekatan saintifik didalamnya. Maka dari itu peneliti tertarik untuk mengembangkan modul kimia pendekatan saintifik supaya bisa membantu meningkatkan hasil belajar peserta didik yang bisa dipelajari secara mandiri. Modul kimia pendekatan saintifik yang dikembangkan ini, supaya bisa membantu siswa belajar sendiri baik dirumah melalui gaya belajar mereka yang bisa memungkinkan peserta didik menemukan suatu konsep pembelajaran yang tidak hanya terpaku pada seorang guru. Menurut (Febrina Kasaomada \& Fitrayati, 2017) proses pembelajaran dengan menggunakan modul berbasis pendekatan saintifik mendapatkan sangat layak dari peserta didik. Hal ini dikarenakan bahwa modul sangatlah menarik dan bisa membangkitkan minat belajar peserta didik. Menurut (Indra Fahrizal \& Wiyanto, 2016) penggunaan modul dalam proses pembelajaran medapatkan respon sangat baik dari peserta didik yaitu mendapatkan skor sebesar 91,33\%.

Modul yang dimaksud ialah modul yang sangatlah perlu dikembangkan dengan menggunakan suatu pendekatan. Dengan adanya suatu pendekatan ini, maka tujuan dalam proses belajar mengajar bisa direncanakan dengan jelas, sehingga pendidik bisa membuat arahan serta sasaran lebih efektif. Dari permasalahan yang sudah diuraikan diatas pendekatan yang tepat ialah Pendekatan Ilmiah. Pendekatan ilmiah ialah proses belajar dimanfaatkan pada tahap ilmiah. Pendekatan ilmiah biasanya juga disebut metode ilmiah. Dapat diartikan, bahwa dalam proses pembelajaran yang dipelajari atau yang didapatkan oleh siswa dilakukan oleh alat penglihatan dan pikiran siswa sendiri, sehingga siswa bisa mendapatkan ilmu pengetahuannya secara langsung (Ghozali, 2017). Penerapan pendekatan saintifik didalam proses pembelajaran akan lebih mudah melaksanakannya apabila terdapat buku. Oleh sebab itu, pelaksanaan proses strategi ilmiah pada suatu modul ialah upaya untuk pendidik dapat membantu dalam menerapkan pendekatan saintifik.

Berdasarkan uraian diatas, peneliti merasa perlu mengembangkan modul kimia strategi ilmiah pada materi laju reaksi kelas sebelas di Madrasah Aliyah Darul Ulum Kubu Raya untuk memenuhi kebutuhan siswa belajar. 


\section{METODE PENELITIAN}

Bentuk penelitian dan pengembangan dipakai ialah penelitian pengembangan. Penelitian pengembangan dengan memakai versi ADDIE sebagai berikut: (1) analyze, (2) perancangan, (3) pengembangan, (4) implementasi, dan (5) evaluasi (Sugihartin, N., \& Yudiana, K. 2018). Namun dalam penelitian pengembangan ini hanya sebatas untuk menentukan kelayakan modul kimia pendekatan saintifik, maka tahap yang dilakukan yaitu analyze, perancangan, serta pengembangan. Pada tahap ini dilakukan karena pada penelitian pengembangan modul kimia pendekatan saintifik terhadap materi laju reaksi hanya sebatas untuk mengenal kelayakan serta tindakan siswa terhadap modul. Adapun prosedur pengembangan modul dengan versi ADDIE bisa terlihat terhadap gambar 1 .

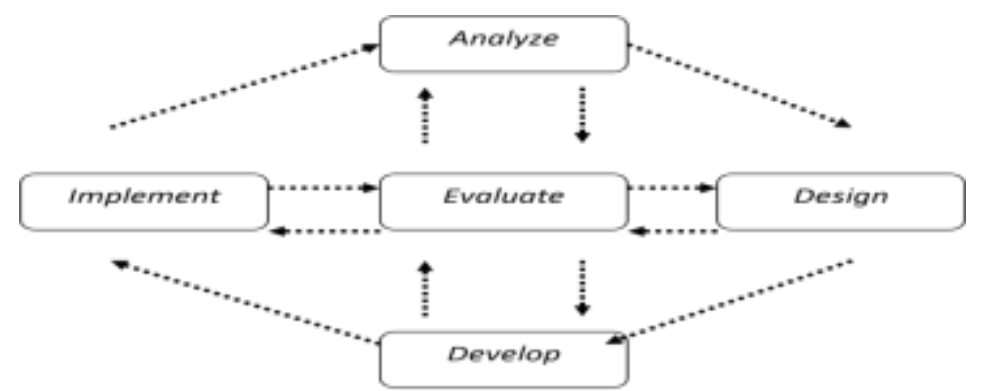

Gambar 1. Model Desain ADDIE(Tegeh \& Kirna, 2013).

Subjek pada analisis disiini ialah bahan ajar kimia Pendekatan Ilmiah materi laju reaksi. Subjek uji cobakan atau sampel pada analisis disini ialah peserta didik kelas sebelas IPA mencakup dua kelas ialah kelas IPA PUTRA serta kelas IPA PUTRI. Uji coba awal yang dilihat dari hasil ulangan harian mereka semester ganjil akan dilakukan kepada 9 orang peserta didik dimana pada setiap kategori masing-masing 3 orang peserta didik memiliki potensi tinggi, rendah serta sedang. Uji lapangan terdapat 19 siswa di setiap kelas sebelas IPA.

Teknik pengumpulan data dilakukan dengan teknik pengukuran ialah dengan menilai kelayakan angket modul kimia pendekatan saintifik berdasarkan validasi isi, validasi penyajian, validasi kebahasaan, serta validasi grafik. Penilaian terhadap modul menggunakan Skala Likert melalui ukuran estimasi 4, 3, 2, serta 1. Hasil dari lembar penilaian kemudian dipakai untuk bahan ulasan serta perbaikan produk yang dibuat. Pada penilaian validasi ini dilakukan oleh masing-masing 3 orang ahli. Sedangkan teknik pengumpulan data pada angket respon peserta didik dilakukan dengan menggunakan teknik komunikasi tidak langsung dalam mengumpulkan data, digunakan supaya bisa mengetahui respon peserta didik pada modul kimia pendekatan saintifik setelah bahan ajar yang digunakan. Angket ini bisa dibagikan untuk siswa setelah uji coba produk.

Teknik analisis data terhadap angket penilaian kelayakan disusun berdasarkan standar kelayakan modul dari Badan Standar Nasional Pendidikan (BSNP) serta disesuaikan melalui keperluan analisis yang terdiri angket untuk memberikan penilaian kelayakan modul berdasarkan isi, penguraian, bahasa, serta grafik. Perolehan dari angket validasi bisa diuraikan menggunakan kegiatan pengolahan data angket penilaian kelayakan Modul Kimia Pendekatan Saintifik ialah: mengukur frekuensi nilai setiap pernyataan, mengukur total nilai setiap pernyataan, mengukur kriteria kelayakan pada setiap pernyataan ditentukan berdasarkan persamaan 1 (Riduwan, 2015).

$$
\mathrm{P}=\frac{\sum \mathrm{X}}{\sum \mathrm{X} \mathrm{i}} \times 100 \%
$$

Melalui:

$\mathrm{P} \quad=$ Presentase perolehan nilai

$\sum \mathrm{X}=$ Total presentase nilai (nilai total) setiap pernyataan

$\sum \mathrm{Xi}=$ Total nilai ideal (nilai tertinggi) 
Setelah memperoleh presentase kelayakan modul secara keseluruhan selanjutnya mengukur penyajian rata-rata kelayakan modul yang ditentukan berdasarkkan persamaan 2 (Riduwan, 2015).

$$
\mathrm{V}=\frac{\sum \mathrm{P} \sum \mathrm{P}}{n n}
$$

Melalui:

$\mathrm{V}=$ Presentase rata-rata kelayakan

$\sum \mathrm{P}=$ Total rata-rata presentase nilai setiap aspek

$\mathrm{n} \quad=$ Total aspek yang dinilai

Angket respon peserta didik menggunakan empat skala Likert meliputi SS, S TS, serta STS. Sebelum diberikan kepada peserta didik, angket divalidasi terlebih dahulu agar angket tersebut layak digunakan sebagai instrument penelitian. Analisis respon dikerjakan memakai skala likert. Kegiatan ini dikerjakan untuk menganalisis angket meliputi: mengukur frekuensi narasumber yang menunjukkan SS, S, TS, serta STS menurut setiap item pernyataan positif dan item pernyataan negatif, mengukur nilai keseluruhan setiap item melalui tolok ukur seperti disajikan pada Tabel 1.

\section{Tabel 1}

Skor Skala Likert Respon Terhadap Modul

\begin{tabular}{ccc}
\hline Kategori & Pernyataan Positif & $\begin{array}{c}\text { Pernyataan } \\
\text { Negatif }\end{array}$ \\
\hline SS & 4 & 1 \\
\hline S & 3 & 2 \\
\hline TS & 2 & 3 \\
\hline STS & 1 & 4 \\
\hline & & (Riduwan, 2015)
\end{tabular}

Mengukur presentase pendapatan nilai total per item ditentukan berdasarkkan persamaan 3 (Riduwan, 2015).

$$
\mathrm{P}=\frac{\sum \mathrm{X}}{\sum \mathrm{X}_{\mathrm{i}}} \times 100 \%
$$

Melalui:

$\mathrm{P} \quad=$ Presentase pendapatan nilai

$\sum \mathrm{X}=$ Total perolehan nilai (nilai total) setiap pernyataan

$\sum \mathrm{Xi}=$ Total nilai yang paling tinggi

Setelah memperoleh presentase prolehan skor per item selanjutnya menghitung presentase total respon ditentukan berdasarkkan persamaan 4 (Riduwan, 2015).

$$
\mathrm{P}_{(\text {total })}=\frac{\sum \mathrm{P} \sum \mathrm{P}}{n n}
$$

Dengan:

$\mathrm{P}_{(\text {total })}=$ Presentase rata-rata respon

$\sum \mathrm{P}=$ Total rata-rata presentase nilai setiap aspek

$\mathrm{n} \quad=$ Total aspek yang dinilai

Selanjutnya tentukan kriteria jawaban tiap pertanyaan melalui tolak ukur pemahaman menurut (Riduwan, 2015) dibawah ini:

$$
\begin{aligned}
\text { Keterangan : Nilai } 0-20 \% & =\text { Sangat Rendah } \\
\text { Nilai } 21 \%-40 \% & =\text { Rendah } \\
\text { Nilai } 41 \%-60 \% & =\text { Cukup } \\
\text { Nilai a } 61 \%-80 \% & =\text { Tinggi }
\end{aligned}
$$


4165 Pengembangan Modul Kimia Pendekatan Saintifik pada Materi Laju Reaksi di Madrasah Aliyah (MA) - Isniatun Hasanah, Husna Amalya Melati, Rahmat Rasmawan

DOI: https://doi.org/10.31004/edukatif.v3i6.746

$$
\text { Nilai } 81 \%-100 \%=\text { Sangat Tinggi }
$$

\section{HASIL DAN PEMBAHASAN PENELITIAN}

\section{Tabel 2}

Hasil Uji Kelayakan terhadap Modul Kimia Pendekatan Saintifik pada Materi Laju Reaksi Menunjukkan Bahwa Modul pada Kriteria Sangat Layak.

\begin{tabular}{crcc}
\hline \multirow{2}{*}{ No. } & \multirow{2}{*}{ Aspek Validasi } & \multicolumn{2}{c}{ Hasil Penelitian } \\
\cline { 3 - 4 } & & Skor Total $(\boldsymbol{\%})$ & Kriteria \\
\hline 1 & Isi & 93,33 & Sangat layak \\
\hline 2 & Penyajian & 86,66 & Sangat layak \\
\hline 3 & Bahasa & 94,66 & Sangat layak \\
\hline 4 & Kegrafikan & 83,99 & Sangat layak \\
\hline & Rata-rata Keseluruhan & 89,66 & Sangat layak \\
\hline
\end{tabular}

Dari hasil penilian kelayakan modul kimia pendekatan saintifik bisa dilihat bahwasannya hasil rata-rata keseluruhan ialah 89,66\% mempunyai kriteria penilaian sangat layak. Menurut (Putri et al., 2019) bahwa modul dikatakan layak ialah media yang layak dilihat dari komponen materi, bahasa, serta kegrafikan. Sehingga modul yang dikembangkan bisa dikatakan layak dan modul ini bisa dimanfaatkan untuk siswa supaya bisa membantu cara belajarnya, artinya melalui bahan ajar ini siswa bisa belajar sendiri baik di rumah maupun di asrama tidak perlu dibimbing oleh pendidik. Hasil yang diperoleh ini, sejalan dengan hasil penelitian (Mufidah, 2014) mengatakan bahwa modul dikatakan layak apabila keseluruhan setelah dianalisis kelayakan mendapatkan nilai $87,33 \%$ memiliki tingkat sangat pantas digunakan sebagai sumber pembelajaran dikelas. Menurut penelitiannya (Setyawati et al., 2016) mengatakan bahwa bahan ajar pendekatan ilmiah dengan menggunakan panduan peta konsep materi koloid telah diperluas termasuk pada tingkat layak untuk dipakai dalam proses pembelajaran serta bisa dipergunakan peserta didik untuk belajar mandiri.

Hal ini bisa ditunjukkan bahwa pada aspek penilaian kelayakan isi dan penyajian Modul Kimia Pendekatan Saintifik mendapatkan rata-rata validasi sebesar 93,33\% dan 86,66\% tercatat pada tingkat sangat pantas diaplikasian. Hal ini bisa dikatakan layak karena sudah mencakup terhadap kesesuaian isi dengan KI KD, bahwa di dalam modul ini sudah mencakup tahap-tahap pendekatan saintifik. Menurut (Setiawan, 2020) tahap proses belajar memakai pendekatan ilmiah ialah (1) melihat, (2) menanyakan, (3) menggabungkan data, (4) menalar, serta (5) mengomunikasikan. Aspek yang diperbaiki dari ahli pada penilaian kelayakan penyajian yaitu: konsep-konsep inti yang terdapat dalam modul kimia pendekatan saintifik. Agar materi ditambahkan dengan beberapa gambar pendukung berhubungan dengan lingkungan sekitar. Dapat terlihat terhadap gambar 2 .

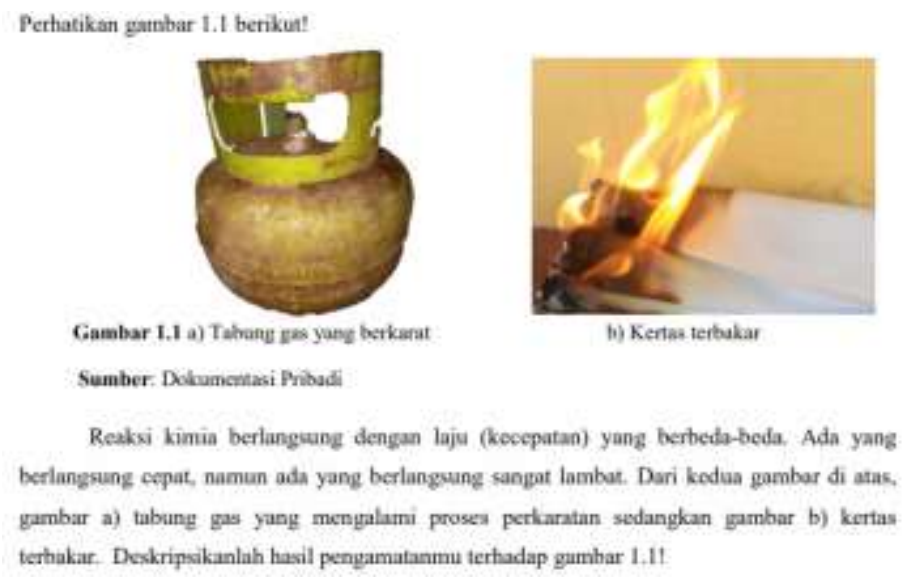

(a)

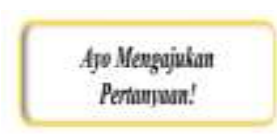

Setah melakkan penganakn, wliskan pertanyan jang Anda bast pada sokm beriku!

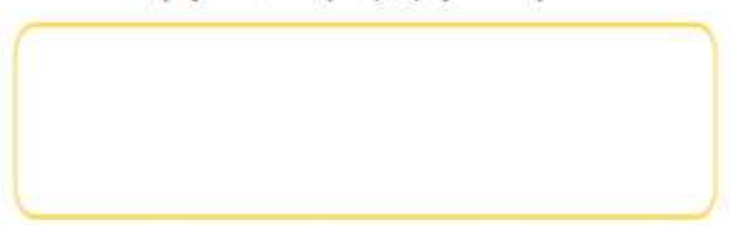




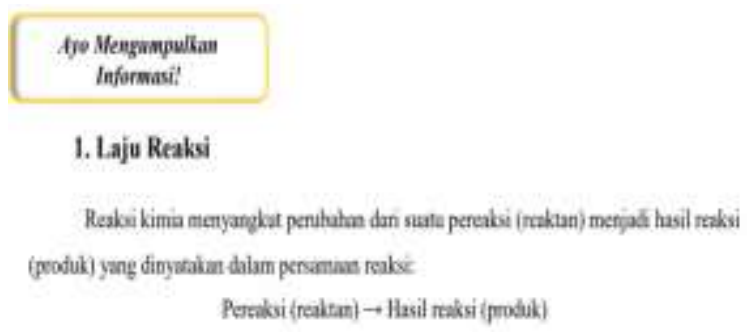

(c)

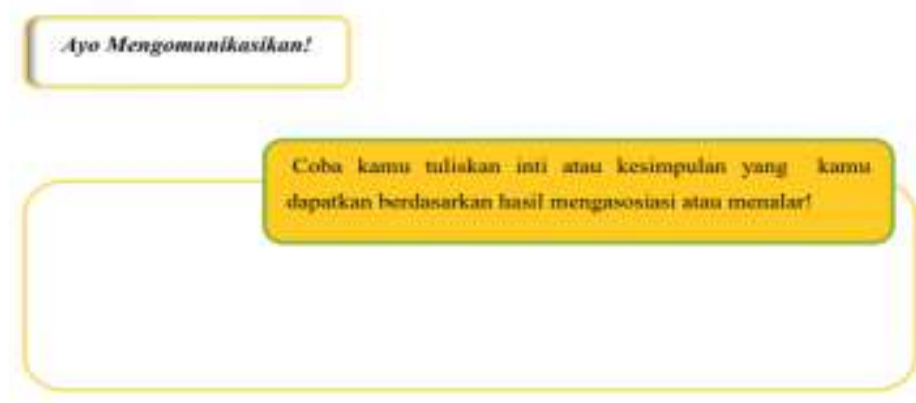

Ayo Menasosiasi atiag

Menalar?

(e)

Gambar 2. Langkah modul pendekatan saintifik; (a) Melihat, (b) menanyakan, (c) menggabungkan data, (d) menalar, serta (e) mengomunikasi.

Pengembangan Modul Kimia Pendekatan Saintifik, isi dari modul yang dikembangkan ini memacu pada bahan ajar yang sering di gunakan didalam kehidupan sehari-hari supaya peserta didik bisa mudah memahami isi dari modul. Didalam menyusun sebuah modul yang dikembangkan ini disusun berdasarkan kebenaran substansi materi pembelajaran. Pada penyusunan modul ini harus disajikan secara urut atau teratur bahwa materi laju reaksi yang disajikan itu memiliki urutan konsep tersendiri. Artinya peserta didik tidak bisa mempelajari materi laju reaksi apabila materi sebelumnya atau prasyaratnya masih belum terpenuhi. Menurut (Budiono \& Susanto, 2006) mengatakan bahwa modul mempunyai beberapa unsur ialah kegiatan belajar, soal, jawaban terhadap soal. Supaya materi bisa dipahami dengan mudah oleh peserta didik, maka perlu disajikan secara sistematis.

Saat proses validasi, terdapat perbaikan dan saran dari validator pada modul kimia pendekatan saintifik sehingga perlu dilakukan evaluasi. Selanjutnya hasil evaluasi digunakan untuk revisi terhadap modul. pada penelitian ini, menggunakan evaluasi formatif yang dilakukan setiap akhir tatap muka. Dengan ini bertujuan untuk memperbaiki kualitas sebuah produk yaitu modul.

Validasi kelayakan bahasa pada saat proses validasi, terdapat perbaikan dan saran dari validator pada aspek bahasa modul kimia Pendekatan Saintifik. Menurut (Sari et al., 2016) menyatakan tata bahasa didalam membuat modul sebaiknya menggunakan tata bahasa yang lebih sederhana yang dapat dipahami. Adapun perbaikan dan saran dari validator ialah: (1) Perbaikan dilakukan terhadap tata bahasa didalam Modul Kimia Pendekatan Saintifik. (2) Perbaikan pada penulisan ejaan yang terdapat beberapa penulisan ejaan yang tidak benar. Ejaan yaitu kaidah pada kata, kalimat dan lainnya didalam suatu bentuk tulisan dan menggunakan tanda baca. Biasanya pada ejaan bukan hanya soal pelambangan fonem pada huruf, akan tetapi diatur juga bagamaina cara penulisan pada kata yang ingin di tulis, penulisan suatu kalimat, dan terdapat tanda bacanya didalam penulisan tersebut (Kurniasari, Nia Andrianti \& Isnaini, 2018). (3) Penulisan daftar pustaka bisa terlihat terhadap gambar 3 . 


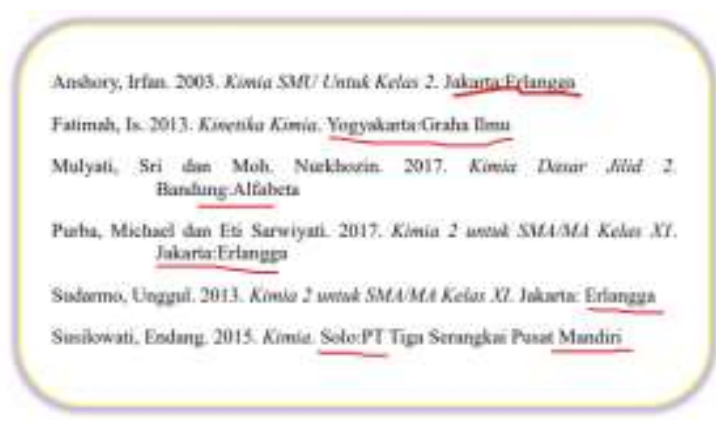

(a)

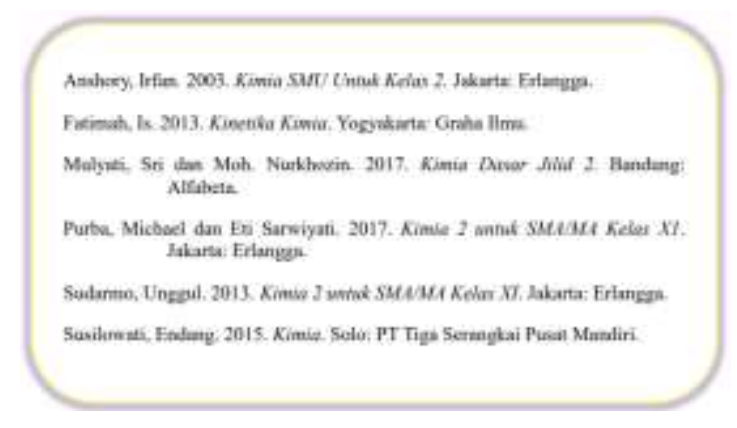

(b)

Gambar 3. (a) sebelum dan (b) sesudah revisi

Validasi kelayakan bahasa dilakukan oleh 3 orang ahli. Dari hasil penilaian para ahli menunjukkan bahwa rata-rata kelayakan kebahasaan Modul Kimia Pendekatan Saintifik memperoleh skor total ialah 94,66\% dengan presentasi kategori sangat layak artinya bahasa yang digunakan tidak mengalami kesulitan ketika mempelajari modul yang sudah dikembangkan. Hal ini menunjukkan bahwa dari aspek kebahasaan modul kimia pendekatan saintifik ini layak diujicobakan.

Validasi kelayakan kegrafikan langkah awal yang harus dilakukan didalam pengembangan modul ialah menetapkan desain atau rancangannya. Dalam hal ini desain dan rancangan modul kimia ditinjau berdasarkan penilaian dari para asper kegrafikan. Pada proses validasi, terdapat beberapa kali perbaikan dan saran dari para validator yaitu pada halaman sampul modul kimia mengalami beberapa kali perbaikan dimana pada sampul modul kimia harus memenuhi kriteria ialah biar meggambarkan isi atau materi serta didalamnya memiliki warna tulisan dibuat berfariasi, ukuran, menggunakan gambar yang ada dilingkungan sekitar, dan proporsi yang disesuaikan dengan realita. Menurut (Hakim, 2018) mengatakan bahwa modul yang dikembangkan harus lebih memperhatikan aspek pada teknis penggunaannya. Sedangkan menurut (S.Sirate \& Ramadhana, 2017) modul yang dikembangkan lebih memperhatikan tata letak yang menarik untuk peserta didik.

Pada sampul modul kimia ini terdapat tulisan "Modul Kimia Pedekatan Saintifik", materi "Laju Reaksi", tedapat logo "UNTAN", "untuk SMA/MA kelas XI, serta tulisan "Nama" penyusun Modul. Pada bagian sampul modul kimia terdapat gambar yang berkaitan dengan isi modul. Sampul pada modul di depan maupun di belakang harus memiliki keterkaitan. Perbaikan sampul modul kimia bisa dilihat pada gambar 4 .
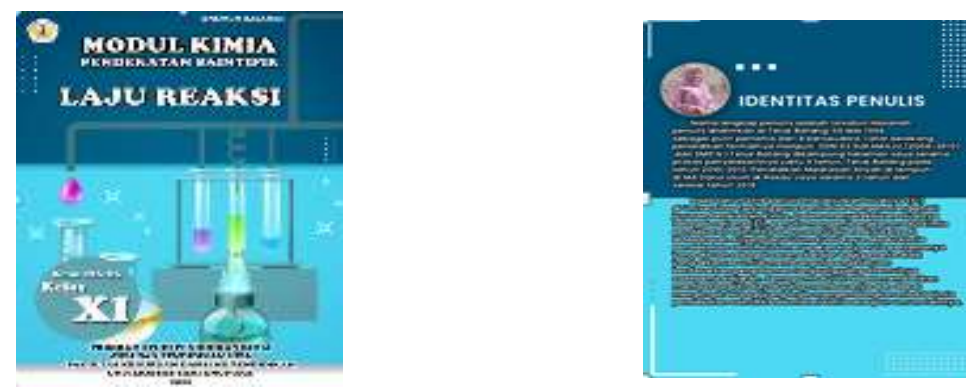

(a) 


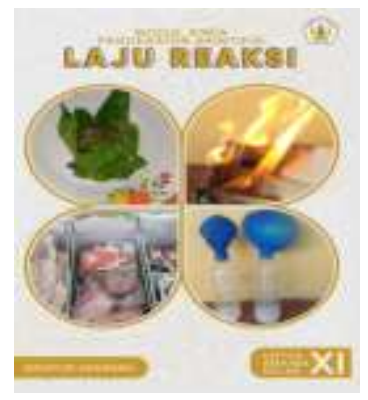

(b)

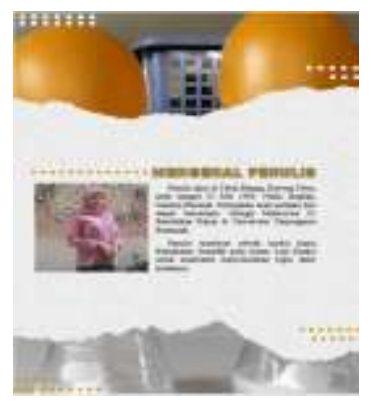

Gambar 4. Tampilan sampul modul bagian depan dan belakang (a) sebelum dan (b) sesudah revisi.

Validasi kelayakan kegrafikan dilakukan oleh 3 orang ahli. Pada penilaian pada modul kimia pendekatan saintifik ini medapatkan skor total $83,99 \%$ memiliki tolak ukur sangat layak. Pada hal ini dapat disimpulkan aspek kelayakan kegrafikan, modul kimia pendekatan saintifik dikembangkan layak diaplikasikan. Hasil penelitian (Mardiani \& Noerhodijah, 2015) menyatakan bahwa desain pada tampilan modul menarik, desain cover dapat menggambarkan isi suatu materi laju reaksi terhadap modul yang dikembangkan, menggunakan font yang mudah dibaca oleh pesera didik, serta urutan materi yang sistematis. Menurut penelitiannya (Sapriah, 2019) bahwa pemakaian modul saat proses belajar bisa membantu mengembangkan motivasi serta minat peserta didik, modul juga bisa membantu meningkatkan pemahaman, penyajiannya yang dibuat menarik dapat mempermudah untuk peserta didik memahami isi dari modul tersebut.

Saat mengumpulkan data hal ini dilaksanakan dengan memberikan lembar penilaian kelayakan untuk setiap tahap. Uji kelayakan dilakukan dengan validasi ahli, ialah aspek materi yang akan memberikan nilai kelayakan pada materi, ahli kebahasaan memberikan nilai kelayakan pada bahasa dan ahli media yang akan memberikan nilai kelayakan pada kegrafikan. Pada perlakuan ini bertujuan supaya bisa melihat kelayakan pada produk awal berdasarkan pada penilain para ahli serta melaksanakan perbaikan menurut ide serta petunjuk para ahli. Validator didalam penelitian ini terdiri dari 3 ahli menilai materi, 3 ahli menilai kebahasaan, serta 3 ahli menilai kegrafikan. Pada lembar penilaian kelayakan Modul Kimia Pendekatan Saintifik ini terdiri tahap materi, tahap kebahasaan, serta tahap kegrafikan mengacu pada standar kelayakan bahan ajar dari Badan Standar Nasional Pendidikan (BSNP).

Tes kelompok kecil dilaksanakan pada 9 siswa dimana pada setiap kategori masing-masing 3 orang peserta didik yang mempunyai kemampuan tinggi, rendah serta sedang. Kesembilan orang peserta didik tersebut diberikan modul kimia pendekatan saintifik pada materi laju reaksi. Pengumpulan data uji coba kelompok kecil (smail group trial) ini meggunakan angket respon siswa yang terdiri dari 3 tahap, ialah kemenarikan, keterpahaman, serta kemudahan.

Tabel 3

Data Hasil Kuesioner Respon Siswa Pada Modul Kimia Pendekatan Ilmiah Untuk Materi Laju Reaksi Uji Coba Kelompok Kecil (Smail Group Trial)

\begin{tabular}{clcc}
\hline No & \multicolumn{1}{c}{ Aspek } & Rata-rata (\%) & Kriteria \\
\hline 1. & Kemenarikan & 87,22 & Sangat Tinggi \\
\hline 2. & Keterpahaman & 87,03 & Sangat Tinggi \\
\hline 3. & Kemudahan & 88,88 & Sangat Tinggi \\
\hline & $\begin{array}{l}\text { Rata-rata angket respon } \\
\text { peserta didik }\end{array}$ & 87,71 & Sangat Tinggi \\
\hline
\end{tabular}

Menurut angket tanggapan siswa tentang modul kimia pendekatan ilmiah untuk materi laju reaksi, pada setiap penilainnya aspek kemenarikan, keterpahaman, serta kemudahan pada modul secara berturut-turut memperoleh presentase skor ialah $87,22 \%, 87,03 \%$ serta $88,88 \%$. Dari hasil yang sudah diperoleh pada setiap 
aspek dirata-ratakan sehingga diperoleh hasil presentase respon peserta didik pada modul kimia pendekatan saintifik pada materi laju reaksi yaitu $87,71 \%$ yang sudah termasuk pada kategori yang sangat tinggi. Hasil dari analisis uji coba skala kecil ini kriteria yang ditinjau dari segi kemenarikan modul. Saran yang sudah diberikan peserta didik mengenai modul ini ialah ketertarikan karena terdapat banyak bacaan.

Setelah melakukan revisi terhadap modul kimia pendekatan saintifik selanjutnya dilakukan uji lapangan (Field Trial) terhadap semua peserta didik kelas XI IPA di MA Darul Ulum yang terdiri dari 19 orang. Hasil tes kelompok lapangan (Field Trial) menggunakan kuesioner peserta didik meliputi 3 tahap, ialah tahap kemenarikan, keterpahaman, dan kemudahan.

Tabel 4

Data Hasil Angket Respon Peserta Didik Terhadap Modul Kimia Pendekatan Saintifik Materi Laju Reaksi tes kelompok besar (Field Trial)

\begin{tabular}{llcc}
\hline No & \multicolumn{1}{c}{ Aspek } & Rata-rata (\%) & Kriteria \\
\hline 1. & Kemenarikan & 89,46 & Sangat Tinggi \\
\hline 2. & Keterpahaman & 87,71 & Sangat Tinggi \\
\hline 3. & Kemudahan & 89,20 & Sangat Tinggi \\
\hline & Rata-rata angket respon peserta didik & 88,79 & Sangat Tinggi \\
\hline
\end{tabular}

Menurut hasil kuesioner sudah diberikan kepada siswa terhadap modul kimia pendekatan ilmiah untuk laju reaksi material dalam pengujian lapangan (Field Trial), pada setiap penilainnya aspek kemenarikan, keterpahaman, serta kemudahan pada modul secara berturut-turut memperoleh presentase skor ialah 89,46\%, $87,71 \%$ serta $89,20 \%$. Dari hasil yang sudah diperoleh pada setiap aspek dirata-ratakan sehingga diperoleh hasil presentase respon peserta didik pada modul kimia pendekatan saintifik pada materi laju reaksi ialah 88,79\% memiliki kategori yang sangat tinggi. Hasil dari analisis bahwa secara keseluruhan modul yang sudah dikembangkan memenuhi kriteria yang diharapkan mulai dari materi, tampilan dan modul. Siswa mengatakan modul sudah baik serta tidak ada saran perbaikan pada modul.

Berdasarkan hasil tes kelompok kecil serta tes kelompok besar, hampir keseluruhannya pada setiap pernyataan terhadap angket respon peserta didik mendapatkan presentase sangat tinggi. Hal ini sejalan dengan penelitiannya (Prabowo et al., 2016) bahwa hasil dari tes kelompok kecil diperoleh total skor 78,54\% termasuk pada kategori valid tanpa revisi sedangkan tes kelompok besar yaitu total skor $80,02 \%$ termasuk kategori valid tanpa revisi. Bahwasannya pada hal ini bisa dikatakan angket respon siswa ini untuk modul kimia pendekatan ilmiah untuk materi laju reaksi sangatlah baik. Hasil dari analisis angket respon siswa yang sudah diperoleh bahwa terdapat 1 butir pernyataan yang mendapatkan kategori tinggi ialah 1 butir pernyataan pada uji coba kelompok kecil (Smail Group Trial). Pada butir tersebut mendapatkan presentase skor 77,78\% karena masih terdapat peserta didik yang masih merasa tidak tertarik untuk membaca modul kimia pendekatan saintifik laju reaksi karena masih banyak bacaan didalamnya. Pengembangan modul kimia pendekatan saintifik ini bisa memudahkan peserta didik untuk mempelajari modul baik secara individu maupun kelompok. Kelebihan dari modul ini supaya peserta didik bisa meningkatkan motivasi belajar karena pada setiap mengerjakan soal yang dibatasi dengan jelas serta sesuai dengan kemampuan individu.

\section{KESIMPULAN}

Dari penelitian ini bisa disimpulkan: (1) modul kimia pendekatan saintifik sangat layak digunakan didalam pembelajaran dengan kriteria sangat layak digunakan terhadap validasi materi, validasi kebahasaan, serta grafik. (2) Respon siswa pada modul kimia pendekatan saintifik pada materi laju reaksi yaitu hasil dari uji coba kelompok kecil (Smail Group Trial) yang termasuk pada kategori sangat tinggi sedangkan pada uji lapangan (Field Trial) yang termasuk pada kategori sangat tinggi. Dengan demikian, modul kimia pendekatan saintifik bisa dimanfaatkan dalam pembelajaran laju reaksi. Modul kimia pendekatan saintifik pada materi laju reaksi bisa dijadikan bahan penelitian lanjutan mengenai efektifitas penerapan bahan ajar untuk dikembangkan didalam proses pembelajaran kimia. 
4170 Pengembangan Modul Kimia Pendekatan Saintifik pada Materi Laju Reaksi di Madrasah Aliyah (MA) - Isniatun Hasanah, Husna Amalya Melati, Rahmat Rasmawan

DOI: https://doi.org/10.31004/edukatif.v3i6.746

\section{DAFTAR PUSTAKA}

Bahtiar, E. T. (2015). Penulisan Bahan Ajar. October. https://doi.org/10.13140/RG.2.1.1441.6083

Budiono, E., \& Susanto, H. (2006). Penyusunan dan Penggunaan Modul Pembelajaran Berdasarkan Kurikulum Berbasis Kompetensi Sub Pokok Bahasan Analisia Kuantitatif untuk Soal-Soal Dinamika Sederhana Pada Kelas X SemesTER I SMA. Jurnal Pend. Fisika Indonesia, 4(2), 79-87. https://doi.org/10.1139/y 72-052

Daryanto, D. A. (2014). Pengembangan Perangkat Pembelajaran (Silabus, Rpp, Phb, Bahan Ajar). Gava Media.

Febrina Kasaomada, P., \& Fitrayati, D. (2017). Pengembangan Modul Berbasis Pendekatan Saintifik Pada Kd 3.8 Mendeskripsikan Pasar Modal Dalam Perekonomian Kelas Xi Ips Sman 1 Mojokerto. Jurnal Pendidikan Ekonomi (JUPE), 5(3). https://doi.org/10.26740/jupe.v5n3.p

Ghozali, I. (2017). Pendekatan Scientific Learning dalam Meningkatkan Prestasi Belajar Siswa. Jurnal Pedagogik, 04(01), 1-13.

Hakim, L. (2018). Pengembangan Media Pembelajaran Pai Berbasis Augmented Reality. Lentera Pendidikan : Jurnal Ilmu Tarbiyah Dan Keguruan, 21(1), 59-72. https://doi.org/10.24252/lp.2018v21n1i6

Indra Fahrizal, P., \& Wiyanto, T. (2016). Penggunaan Modul Pembelajaran Berbasis Komputer (CAD) Untuk Meningkatkan Hasil Belajar di Smk Negeri 3 Jombang. 04(02), 85-92.

Kurniasari, Nia Andrianti, V., \& Isnaini, H. (2018). Analisis Kesalahan Ejaan Pada Salah Satu Judul Berita “ Isu Tka Digoreng Menjelang Pilpres " Pada Surat Kabar Tribun Jabar Edisi 25 April 2018. Jurnal Pendidikan Bahasa Dan Sastra Indonesia, 1(4), 527-534.

Mardiana, E. (2018). Pengembangan Bahan Ajar Berbasis Pendekatan Saintifik Meningkatkan Kemampuan Literasi Matematika Siswa. Prisma, Prosiding Seminar Nasional Matematika, 1, 87-91.

Mardiani, E., \& Noerhodijah, S. R. (2015). Penyusunan Modul Pembelajaran Jaringan Tumbuhan Berbasis Hakikat Sains. Biodidaktika, 10(2), 1-8.

Mufidah, C. I. (2014). Pengembangan Modul Pembelajaran Pada Kompetensi Dasar Hubungan Masyarakat Kelas X Apk 2 Di Smkn 10 Surabaya. Jurnal Administrasi Perkantoran, 2(2), 1-17.

Mustika, N., \& Sophia, A. (2019). Pengembangan Modul English In Analyzer Dalam Peningkatan Kemampuan Berbahasa Inggris Bagi Mahasiswa Analis Kesehatan. EDUKATIF: Jurnal Ilmu Pendidikan, 1(3), 107-112. https://edukatif.org/index.php/edukatif/index

Prabowo, C. A., Ibrohim, \& Saptasari, M. (2016). Pengembangan Modul Pembelajaran Inkuiri Berbasis Laboratorium Virtual. Jurnal Pendidikan - Teori, Penelitian, Dan Pengembangan, 1(6), 1090-1097. https://doi.org/10.17977/jp.v1i6.6422

Putri, R. M., Risdianto, E., \& Rohadi, N. (2019). Pengembangan Media Pembelajaran Interaktif Dengan Menggunakan Adobe Captivate Pada Materi Gerak Harmonik Sederhana. Jurnal Kumparan Fisika, 2(2), 113-120. https://doi.org/10.33369/jkf.2.2.113-120

Riduwan. (2015). Dasar-Dasar Statistik. CV. Alfabeta.

S.Sirate, S. F., \& Ramadhana, R. (2017). Pengembangan Modul Pembelajaran Berbasis Keterampilan Literasi. Inspiratif Pendidikan, 6(2), 316-335. https://doi.org/10.24252/ip.v6i2.5763

Sapriah. (2019). Media Pembelajaran Dalam Proses Belajar Mengajar. Prosiding Seminar Nasional Pendidikan FKIP, 2(1), 470-477. https://doi.org/10.35446/diklatreview.v3i1.349

Sari, J. I., Syamswisna, \& Yokhebed. (2016). Kelayakan Bahan Ajar Modul Pada Materi Keanekaragaman Hayati Kelas X Sma. Jurnal Ilmiah Mahasiswa FKIP UNTAN, 1(2), 1-11. 
4171 Pengembangan Modul Kimia Pendekatan Saintifik pada Materi Laju Reaksi di Madrasah Aliyah (MA) - Isniatun Hasanah, Husna Amalya Melati, Rahmat Rasmawan

DOI: https://doi.org/10.31004/edukatif.v3i6.746

Sawitri, D. W., \& Ambarwati, R. (2014). Pengembangan Modul Keanekaragaman Hayati Berbasis Pendekatan Saintifik Untuk Siswa KELAS X SMA. 3(3), 410-415.

Setiawan, R. A. (2020). Lembar Kegiatan Literasi Saintifik untuk Pembelajaran Jarak Jauh Topik Penyakit Coronavirus 2019 (COVID-19). Edukatif: Jurnal Ilmu Pendidikan, 2(1), 28-37.

Setyawati, R., Mulyani, S., \& Ashadi. (2016). Pengembangan Modul Kimia Berbasis Saintifik 5M dengan Panduan Mind Mad pada Materi Koloid. Seminar Nasional Pendidikan Sains, 199-204.

Suryosubroto. (2009). Proses Belajar Mengajar di sekolah. Rineka Cipta.

Tegeh, I. M., \& Kirna, I. M. (2013). Pengembangan Bahan Ajar Metode Penelitian Pendidikan dengan ADDIE Model. Jurnal Pendidikan, 11(1), 16. 